\title{
THE CRIMINAL ENFORCEMENT OF ANTITRUST LAW - THE IMPORTANCE OF BUILDING AN ENFORCEMENT CULTURE AND HOW TO CREATE IT
}

\author{
Peter O'Loughlin*
}

\begin{abstract}
There has been a proliferation of jurisdictions across the world seeking to use criminal sanctions to deter and punish cartels and many have enacted laws that criminalise this type of anticompetitive behaviour. However, other jurisdictions have failed to replicate the enviable success of the US. Reports to the OECD suggest that they have encountered difficulties ranging from procedural to legal, but also disincentives on the part of key players - like judges, the general public, prosecutors, and government - in the actual enforcement of such a regime. These experiences intimate that some of these jurisdictions - awestruck by the accomplishments of the US - have not developed the enforcement culture necessary to effectively implement and maintain a criminalised antitrust regime. This essay puts forward a rhetorical framework that other countries may draw upon when attempting to garner both public and political support in the criminalisation process. It will be argued that because of the global financial crisis leaving many countries in dire straits, regulators must seize this opportunity to leverage the universal concepts of inequality and financial hardship in demonstrating the pernicious nature of cartels and, as a result, highlight why the case for criminalisation is so strong.
\end{abstract}

\section{A. INTRODUCTION}

Justice Scalia described hardcore cartel activity ${ }^{1}$ as 'the supreme evil' of antitrust in Trinko. ${ }^{2}$ The Organisation for Economic Co-operation and Development (OECD) also referred to this type of behaviour as 'the most egregious' violation of competition law. ${ }^{3}$ Indeed, such activity has been shown to increase the prices of goods and services artificially, reduce consumer welfare, and disincentivise businesses to innovate and respond to market changes. ${ }^{4}$ As the OECD explains:

A successful cartel raises prices above the competitive level and reduces output. Consumers choose either not to pay the higher price for some or all of the cartelised

\footnotetext{
* Graduate Teaching Fellow, University College London (UCL), peter.o'loughlin.13@ucl.ac.uk. This paper was written primarily during the summer of 2014 when I was an LLM student at UCL. Since then, I have had the privilege to remain here - both as a teacher and researcher - and wish to extend gratitude to the following people: Florian Wagner; Arad Reisberg; Anna Donovan; Despoina Mantzari; Ioannis Lianos; Martin Petrin; Iris Chiu; and lastly, Valentine Korah, whose pioneering of, and contribution to, European Competition law requires no explanation - I thank her for both her guidance and friendship. Responsibility for errors or omissions in this essay lie solely with me, and the views/opinions expressed herein are mine alone.

${ }^{1}$ Anti-competitive arrangements between competitors to fix prices, rig bids, restrict output, or share markets.

${ }^{2}$ Verizon Communications Inc. $v$ The Law Offices of Curtis Trinko 540 US 398 (2004).

3 'Antitrust law' and 'Competition law' are used synonymously in this essay.

${ }^{4}$ OECD, Report on the Nature and Impact of Hard Core Cartels and Sanctions Against Cartels Under National Competition Laws (DAFFE/COMP7 2002) 2.
} 
product that they desire, thus forgoing the product, or they pay the cartel price and thereby unknowingly transfer wealth to the cartel operators. Further, a cartel shelters its members from full exposure to market forces, reducing pressures on them to control costs and to innovate. All of these adversely affect efficiency in a market economy. ${ }^{5}$

As consensus around the economic harm caused by cartels has grown, so too has the debate about how best to tackle cartel activity, reflect its seriousness, and 'ensure that it is detected, deterred, and punished'. ${ }^{6}$ Recently, there has been a proliferation of jurisdictions across the world seeking to use criminal sanctions to deter and punish this type of anticompetitive behaviour, and many have enacted laws that criminalise cartel activity. ${ }^{7}$ This is a product of the worldwide trend towards tougher sanctions against cartels advocated, in particular, by international organisations. ${ }^{8}$ Competition authorities also now work more closely together, for example through the International Competition Network (ICN). ${ }^{9}$ As Scott Hammond summarises: ${ }^{10}$

In the last two decades, the world has seen the proliferation of effective leniency programs, ever-increasing sanctions for cartel offenses, a growing global movement to hold individuals criminally accountable, and increased international cooperation among enforcers in cartel investigations. ${ }^{11}$

With respect to criminal sanctions, their greatest proponent, and the most successful in their utilisation, has been the US. Criminal antitrust enforcement in this jurisdiction boasts a formidable record. As Joel Davidow commented in 2004:

In the last fiscal year, defendants in [Department of Justice] Antitrust Division cases were sentenced to more than 10,000 jail days - a record - with an average sentence of more than 18 months. In the last four years, a total of over 75 years of imprisonment

\footnotetext{
5 ibid.

${ }^{6}$ Alison Jones and Rebecca Williams, 'The UK Response to the Global Effort against Cartels: Is Criminalization Really the Solution?' (2014) Journal of Antitrust Enforcement 1-26, 1.

${ }^{7}$ Gregory Shaffer, Nathaniel Nesbitt, and Spencer Waller, 'Criminalizing Cartels: A Global Trend?' (2011) 12 Sedona Conference Journal Minnesota Legal Studies Research Paper No. 11-26, 8-9.

${ }^{8} \mathrm{OECD}$, Recommendation of the Council Concerning Effective Action Against Hard Core Cartels (C(98)35/Final 1998).

${ }^{9}$ International Competition Network <http://www.internationalcompetitionnetwork.org/> accessed 16 August 2014.

${ }^{10}$ US Deputy Assistant Attorney General for Criminal Enforcement of the Antitrust Division at the Department of Justice.

${ }^{11}$ Scott Hammond, 'The Evolution of Criminal Antitrust Enforcement Over the Last Two Decades' (24th Annual National Institute on White Collar Crime, Miami, Florida, 25 February 2010).
} 


\section{The Criminal Enforcement of Antitrust Law - The Importance of Building an Enforcement Culture and How to Create it}

have been imposed on antitrust defendants, with more than 30 defendants receiving prison sentences of one year or longer. ${ }^{12}$

This impressive record continues today. During the 2010-2013 period, the number of individuals sentenced to incarceration was 123 and the total amount of incarceration time imposed by the Court was 250 years. ${ }^{13}$

The general premise of the justification for such sanctions is that because it is individuals who engage the cartel in the first place, imprisonment is arguably the most efficacious way to deter this type of behaviour. 'Illegal conspiracies do not exist in the abstract; active participation by particular individuals is essential to the success of any conspiracy'. ${ }^{14}$

Yet despite the attractiveness of criminal sanctions, other jurisdictions have failed to replicate the success of the US. Reports to the OECD suggest that countries that have joined the criminalisation movement have encountered difficulties ranging from procedural to legal, but also disincentives on the part of key players - like judges, the general public, prosecutors, and government - in the actual enforcement of such a regime. ${ }^{15}$ For example, the UK Government criminalised cartel behaviour under Part 6 Enterprise Act 2002. ${ }^{16}$ However, instead of the 6-10 prosecutions per year initially predicted, only three individuals have been prosecuted to date, all in relation to just one cartel - Marine Hoses ${ }^{17}$ Furthermore, the ultimate prosecution of this cartel was largely down to help from the US.

These experiences intimate that actually, some of these jurisdictions - awestruck by the accomplishments of the US - have not developed the enforcement culture necessary to effectively implement and maintain a criminalised antitrust regime. '[W]ithout broad-ranging acceptance and support domestically, the rhetoric of regulators in local and international fora may not be sufficient to secure the effective enforcement of criminal provisions. ${ }^{18}$ Therefore, jurisdictions contemplating criminalisation must be prepared to engage in a process that creates and fosters an enforcement culture. Indeed, a 'major part of the [US] story is the belief, shared

\footnotetext{
12 Joel Davidow, 'Recent US Antitrust Developments of International Relevance' (2004) 27 World Competition 407, 409.

${ }^{13}$ DOJ Antitrust Division, 'Workload Statistics FY 2004-2013'< <http://www.justice.gov/atr/public/workload-

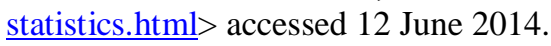

${ }^{14}$ Donald Baker, 'Deterring Cartels - the Criminalization Dimension' (Competition Law Enforcement Seminar, Dublin, 23 March 2012) 11.

15 Christopher Harding, 'Business Collusion as a Criminological Phenomenon: Exploring the Global Criminalisation of Business Cartels’ (2006) 14 Critical Criminology 181, 192-194.

${ }^{16}$ Enterprise Act 2002, s 190(1).

${ }^{17} R v$ Whittle \& Others [2008] EWCA Crim 2560.

18 Caron Beaton-Wells, 'Criminalising Cartels: Australia's Slow Conversion' (2008) 31 World Competition 205 , 206.
} 
by the enforcers and much of the public, that highly visible jail sentences are the most effective way to deter cartel activities'. ${ }^{19}$

On these foregoing points, this paper argues that criminal sanctions work in the US largely due to an enforcement culture that politically and publicly recognises the negative influence of cartels, recognises the efficacy of criminal sanctions to effectively deter and punish this activity, and uses specific investigatory and procedural processes - all of which can be regarded as "peculiarly American". ${ }^{20}$ It will be concluded that other countries, seeking to emulate the US, must realise that success will not be derived overnight: it will be the product of pragmatic efforts to persuade key stakeholders of criminal antitrust enforcement's value and effectiveness.

First, the general rationale for criminalisation will be explained - specifically, the inadequacy of fines, the issue of 'agency', and the fear that consumers may actually suffer from the imposition of corporate fines. Second, the particularities of the American antitrust regime will be detailed, revealing the predominant reasons for its accomplishments. Third, and building on this latter section, reference will be made to the UK, using it as an example to demonstrate the consequences that follow from not building an enforcement culture. The UK's lethargic efforts before, during, and after the criminal cartel offence was created, failed to generate the support of key stakeholders that is necessary for a successful criminalised antitrust regime. Fourth, it will be explained why the support of key stakeholders - such as the judiciary, general public, and government - is necessary. Following this, with reference to Australia, this paper will put forward a rhetorical framework that other countries may draw upon when attempting to garner both public and political support in the criminalisation process. It will be argued that because of the global financial crisis leaving many countries in dire straits, regulators must seize this opportunity to leverage the concepts of inequality and financial hardship in demonstrating the pernicious nature of cartels and, as a result, highlight why the case for criminalisation is so strong. They must take steps 'to create, in part through the process of criminalisation itself, a strong sense of the unacceptability of the conduct in question, within the industry in question, and beyond' ${ }^{21}$

\footnotetext{
${ }^{19}$ Donald Baker, 'Punishment for Cartel Participants in the US: A Special Model?' in Caron Beaton-Wells and Ariel Ezrachi (eds), Criminalising Cartels: Critical Studies of an International Regulatory Movement (Hart Publishing 2011) ch 2.

${ }^{20}$ ibid.

${ }^{21}$ Law Commission Consultation Report 195, Criminal Liability in Regulatory Contexts: A Consultation Paper (2010).
} 


\section{The Criminal Enforcement of Antitrust Law - The Importance of Building an Enforcement Culture and How to Create it}

\section{B. WHY CRIMINALISATION?}

Deterrence is the primary rationale for criminalising antitrust infringements. At its most basic, and as stated at this paper's outset, individuals instigate cartel activity. ${ }^{22}$ It has therefore been argued that corporate fines alone are inappropriate because they fail to target the individuals responsible. ${ }^{23}$ Drawing on corporate governance literature relating to agency theory, the following paragraphs will show why individuals' incentives may not be aligned with the company's, thereby increasing their proclivity (especially in an economic recession) to initiate a cartel without any concern for the consequences. The inadequacy of corporate fines will also be evinced, showing that they would have to be impossibly high to ensure deterrence. It will ultimately be concluded that because it is individuals who instigate price-fixing, it makes sense to concentrate deterrence on those who actually engage in the prohibited behaviour. ${ }^{24}$

Individuals fix prices, not companies:

As agents of corporations commit violations of competition law, it makes sense to prevent them from engaging in unlawful conduct by threatening them directly with sanctions and to impose such sanctions if they violate the law. ${ }^{25}$

Indeed, Baker notes from his experience that those who engage in cartel activity are 'generally ambitious individuals seeking promotion, reputation enhancement, bonuses, or other indirect gains from appearing to have been more successful commercially than they really were' ${ }^{26}$ This is also the experience of Calvani and Calvani, ie it is usually middle-management who engage in this behaviour. ${ }^{27}$

Company officers and employees are agents of corporations. Agency is 'a contract under which one or more persons (the principal(s)) engage another person (the agent) to perform some service on their behalf which involves delegating some decision making authority to the agent'. ${ }^{28}$ A typical example is the relationship between shareholder and director. The main dilemma stemming from such relationships is that the principal and agent, whilst ostensibly working towards the same object, may not share corresponding interests. Therefore, '[i]n most agency relationships ... there will be some divergence between the

\footnotetext{
22 Baker, 'Deterring Cartels - the Criminalization Dimension' (n 14).

${ }^{23}$ Wouter Wills, 'Is Criminalization of EU Competition Law the Answer?' (Amsterdam Centre for Law and Economics Conference: Remedies and Sanctions in Competition Policy, Amsterdam, 17-18 February 2005).

${ }^{24}$ Calvani and Calvani, 'Criminal Sanctions for Cartel Offences: An Appropriate Sanction in Australia' (2009) 17 Competition \& Consumer Law Journal 119, 127-128.

${ }^{25}$ OECD, Cartel Sanctions Against Individuals (DAF/COMP(2004)39 2005) 16. (emphases added)

${ }^{26}$ Baker, 'Punishment for Cartel Participants in the US: A Special Model?' (n 19).

${ }^{27}$ Calvani and Calvani (n 24) 127.

${ }^{28}$ Michael Jensen and William Meckling, 'Theory of the Firm: Managerial Behavior, Agency Costs and Ownership Structure' (1976) 3(4) Journal of Financial Economics 5.
} 
agent's decisions and those decisions which would maximize the welfare of the principal. ${ }^{29}$ The principal's problem is incentivising the agent to satisfy the principal's objectives; the agent's problem is that situations may arise where the agent can act in the principal's interest, the agent's own interest, or some compromise between the two when these interests are incongruent and possibly competing. ${ }^{30}$

Jensen and Meckling explain this by contrasting management behaviours in two different scenarios: where the manager owns 100 percent of the company, and where the manager sells equity to outside investors. ${ }^{31}$ In the former scenario, the agency problem does not exist because the owner-manager will endeavour to maximise company welfare - the whole benefit accumulating only to him. Maximisation occurs when the marginal utility of each spent dollar equals the non-monetary benefits (eg employee respect, workforce size) and the marginal utility of each after-tax dollar. However, if the owner-manager sells 30 percent of the company, agency costs emerge due to the disparity of interests between the manager and new shareholders. Here, the owner-manager's wealth reduces to 70 percent. His proclivity to expend resources will be such that one dollar used equals the marginal utility of 70 cents of spending power, ie a reduction equal to the wealth share reduction.

Agency costs might include the greater need of outside shareholders to monitor the owner-manager's behaviour. ${ }^{32}$ Other costs are more serious, like the agent's reluctance to seek out new business ventures. Actually, he might avoid these altogether simply because it would require too much effort. For example, he may have to work harder to learn new technologies, or hire special consultants resulting in lengthy selection and appointment processes. In attempting to avoid such personal hardships, company value is undermined, decreasing it to a lower level than it otherwise could have been. In the end, the agent might simply decide that it would be easier to raise company performance (and thereby the agent's own reputation) by initiating a price-fixing cartel with other competitors, than by any of the traditional methods.

Indeed, anecdotal evidence by Baker suggests that managers who act on such impulses are generally apathetic to the consequences for the company, and 'never seem to have worried particularly about the corporate shareholders being socked with large fines ... Rather, to the extent that they have worried, their concern was about being exposed and punished

\footnotetext{
29 ibid.

${ }^{30}$ Barry Mitnick, 'Fiduciary Rationality and Public Policy: The Theory of Agency and Some Consequences' (1973 Annual Meeting of the American Political Science Association, New Orleans, Louisina, September 1973) <http://papers.ssrn.com/sol3/papers.cfm?abstract_id=1020859> accessed 11 August 2014.

31 Jensen and Meckling (n 28) 10-11.

32 ibid 12.
} 


\section{The Criminal Enforcement of Antitrust Law - The Importance of Building an Enforcement Culture and How to Create it}

themselves'. ${ }^{33}$ Furthermore, the risk of collusion between companies is exacerbated in a recession. Employees are under pressure to perform at a level that is more difficult in the current financial climate and, as a result, they may decide that it would be easier to achieve performance targets through a cartel than it would be through conventional means. This risk is compounded by the fact that in a recession, managers and in-house counsel may not be able to afford as much time and resources towards developing compliance programs and emphasising their importance to subordinate employees. ${ }^{34}$ On this analysis, therefore, corporate fines may not be adequate because it is the company's individuals who make the decisions and as such commit the crimes. In contrast, '[b]y targeting the actual decision-maker, competition authorities could bypass ineffective corporate governance mechanisms of compliance and indirect punishment' ${ }^{35}$

Another reason why corporate fines are inadequate is that they would have to be unfeasibly high to ensure deterrence. ${ }^{36}$. Theoretically, fines should be preferred over custodial sentences, as they impose less of a cost on society. However, effective deterrence requires that a prospective cartelist perceive the expected costs of price fixing to outweigh the potential benefit.

The benefit is the over-charge of the product, yet expunging this would still not achieve optimal deterrence because only a fraction of cartels are detected. As such, the fine would therefore have to be increased to take account of the probability (or more aptly the improbability) of detection. Two investigators explored this issue in the US. They found that only 13-17 percent of price-fixers were ultimately prosecuted successfully. ${ }^{37}$

Even with an increase, however, corporate fines would still have to be impossibly high. For instance, Wouter Wills maintains that fines would have to be somewhere around 150 percent of annual turnover to ensure deterrence. ${ }^{38}$ This is impractical for a number of reasons. First, it would be unacceptable in the EU because of the statutory ceiling of 10 percent under

\footnotetext{
${ }^{33}$ Baker, 'Punishment for Cartel Participants in the US: A Special Model?' (n 19).

${ }^{34}$ Janet McDavid and Megan Dixon, 'Criminal Antitrust Enforcement in a Down Economy' (Lexology, 28 May 2009) <http://www.lexology.com/library/detail.aspx?g=8bd04582-1700-478b-9022-6a97c74a0d46> accessed 9 August 2014.

35 Katalin Cseres, Maarten Schinkel, and Floris Vogelaar, 'Law \& Economics of Criminal Antitrust Enforcement: An Introduction' in Katalin Cseres, Maarten Schinkel, and Floris Vogelaar (eds) Criminalisation of Competition Law Enforcement: Economic and Legal Implications for the EU Member States (Edward Elgar Publishing 2006) 7-8.

${ }^{36}$ Calvani and Calvani (n 24) 128.

37 ibid citing Peter Bryant and E Woodrow Eckard, 'Price-fixing: The Probability of Getting Caught' (1991) 73 Review of Economics and Statistics 531.

${ }^{38}$ Wouter Wills, 'Does the Effective Enforcement of Articles 81 and 82 EC Require Not Only Fines On Undertakings But Also Individual Penalties, In Particular Imprisonment?' (Competition Law and Policy Workshop at the European University Institute, Florence, 1-2 June 2001).
} 
Article 23(2) Regulation 1/2003. ${ }^{39}$ Second, and more generally, high fines might exceed an undertaking's ability to pay, resulting in not just sub-optimal enforcement due to incomplete deterrence, but also costly side effects like company bankruptcy and, consequently, undesirable social consequences like job losses or strains on a country's exchequer. Third, and paradoxically from a competition law perspective, the company, if it survived the fine, might decide to offset the cost by passing it on to consumers in the form of higher prices. And if firms did go bankrupt, this might lead to greater market concentration - another (generally) undesirable outcome from a competition law perspective. Indeed, one study suggests that sixty percent of firms would be unable to meet the demand of high fines without incurring bankruptcy. ${ }^{40}$

UK Independent Schools aptly illustrates this particular defect of corporate fines. ${ }^{41}$ The Office of Fair Trading (OFT) found that information exchanges regarding fees between 50 feepaying independent schools constituted a Chapter 1 infringement. However, the schools were ultimately made to pay a $£ 3$ million ex gratia payment to a trust, which would benefit those who attended the schools during the infringement period. In return, the fine imposed was substantially reduced for each school. This was sensible because a heavy fine may have led to an increase in tuition fees, which would only have served to further harm students.

There is another, peripheral rationale for cartel criminalisation. It has the ability to enhance a competition authority's corporate leniency programme - an enforcement tool that will now be examined in the broader context of the US.

\section{WHY HAS CRIMINALISATION BEEN SO SUCCESSFUL IN THE UNITED STATES?}

Sherman Act violations have traditionally been punishable with criminal fines for companies and individuals, and imprisonment also for the latter. ${ }^{42}$ Whilst the original Sherman Act in 1890 encompassed these penalties, it was not until about 70 years later that jail time for perpetrators would begin to become commonplace. ${ }^{43}$-The following paragraphs will show that the process

\footnotetext{
${ }^{39}$ Council Regulation (EC) 1/2003 of 16 December 2002 on the implementation of the rules on competition laid down in Articles 81 and 82 of the Treaty [2003] OJ L1/1.

${ }^{40}$ Joseph Gallo, Joseph Craycraft, and Catherine Craycraft, 'Antitrust Sanctions and a Firm's ability to Pay' (1997) 12 Review of Industrial Organisation 171.

${ }^{41}$ OFT Decision CA98/05/2006.

42 Sherman Act, 26 Stat 209 (1890), 15 USC ss 1-7.

${ }^{43}$ Keith Jones and Farin Harrison, 'Criminal Sanctions: An Overview of EU and National Case Law' (Baker \& McKenzie, 25 March 2014) <http://www.bakermckenzie.com/ARAPCriminalSanctionsMar14/> accessed 15 July 2014.
} 


\section{The Criminal Enforcement of Antitrust Law - The Importance of Building an Enforcement Culture and How to Create it}

was indeed gradual, progressive, and incremental, distinguished by 'cultural assumptions and political traditions [that] have been so important in shaping the process' ${ }^{44}$ US enforcement authorities have also benefited from several distinct investigatory and procedural tools: interrelated corporate and individual leniency programmes; a combined civil and criminal enforcement entity; and grand jury trials. This section will conclude that other jurisdictions considering criminal enforcement may be hard set to find substantive guidance from the US, as 'it clearly rests on cultural assumptions and its legal institutions which may not be repeated elsewhere'. ${ }^{45}$

The original Sherman Act statute made antitrust violations misdemeanours and imposed a maximum jail time of one year and a maximum fine of $\$ 5,000$. The Act came about because of populist outrage, 'rather than being the product of careful study by some learned commission'. ${ }^{46}$ As a consequence, antitrust has always had a strong moral dimension in the US. As Robert Reich commented in 1980, 'antitrust is popular with the public' and 'the ideal of competition [continues] to receive broad support from a wide spectrum of American public opinion'. ${ }^{47}$ Similarly, as Baker has explained, price-fixing is viewed as immoral, like theft. ${ }^{48}$ These original Sherman Act sanctions remained in place all the way up until 1974, when the Act was amended so that violations of its provisions became felonies. ${ }^{49}$ Corporate fines increased and individuals found guilty of violating the legislation could now be imprisoned for 3 years.

In 1987, the Sentencing Guidelines ${ }^{50}$ resolved the quandary judges had with imprisoning what they saw as 'nice people'. ${ }^{51}$ Many federal judges were reluctant to sentence price-fixers, as they were often prominent public figures in their communities who contributed to churches and charities. Moreover, once price-fixers were apprehended they tended to show remorse and were perceived as showing no physical threat to other members of society. ${ }^{52}$ The Sentencing Guidelines made prison the immediate remedy, however. They were mandatory until United States $v$ Booker ${ }^{53}$ which ruled that such mandatory use was unconstitutional. By

\footnotetext{
${ }^{44}$ Baker, 'Punishment for Cartel Participants in the US: A Special Model?' (n 19).

${ }^{45}$ Baker, 'Deterring Cartels - the Criminalization Dimension' (n 14) 1.

46 ibid 3.

47 Robert Reich, 'The Antitrust Industry' (1980) 68 Georgetown Law Journal 1035, 1054.

${ }^{48}$ Donald Baker, 'The Use of Criminal Law Remedies to Deter and Punish Cartels and Bid-Rigging (2001) 69 George Washington Law Review 693, 714; Baker, 'Deterring Cartels - the Criminalization Dimension' (n 14).

${ }^{49}$ Antitrust Procedures and Penalties Act, 88 Stat 1706 (1974), Public Law 93-528, s 3(1).

${ }^{50}$ US Sentencing Commission, 'Sentencing Guidelines and Policy Statements' (1987).

${ }^{51}$ Baker, 'Punishment for Cartel Participants in the US: A Special Model?' (n 19).

52 ibid.

${ }^{53} 543$ US 220 (2005).
} 
this time it was too late, though: the Guidelines had already generated a norm such that taking away their formal compulsory use did not change the fact that judges would continue to opt to use them anyway, as they had done for so long. As one criminal antitrust defence lawyer explained, '[b]ecause of the sentencing Guidelines and the unwavering determination of the Antitrust Division, the US antitrust defendant almost always understands that the question is not whether he will go to prison, but for how long'. ${ }^{54}$ Finally, in 2004, the maximum corporate and individual fines for violations of the Sherman Act rose to \$100 million and \$1 million respectively; the maximum jail term was increased to 10 years.

In light of these developments, other jurisdictions contemplating criminal antitrust enforcement should not expect immediate results. By using 'gentle nudges' instead of 'hard shoves', the US avoided what Kahan terms 'sticky norms'. ${ }^{55}$ It was a step-by-step process, with the severity of the penalty increasing gradually. However, as previously mentioned, criminalisation in the US was a bottom-up process anyway, and so it is arguable that a norm did not really exist to the effect that price-fixing should not be subject to criminal sanctions. In any event, the US, albeit inadvertently, made sure that any such norm did not come into play, as the law slowly but surely condemned price-fixing. As Kahan contends:

If the law condemns [price-fixing] substantially more than does the typical [judge, jury, or enforcement official, their] personal aversion to condemning too severely will dominate [their] inclination to enforce the law, and [they] will balk... If, however, the law condemns the behaviour only slightly more than does the typical [judge, jury, or enforcement official, their] desire to discharge [their] civic duties will override [their] reluctance to condemn, and [they] will enforce the law. ${ }^{56}$

Other jurisdictions considering criminalising antitrust offences - the majority of which will almost certainly be a top-down process - should take heed of this subtle lesson.

The US success is also based on a number of unique investigatory and procedural tools. Under the Corporate Amnesty Programme, ${ }^{57}$ the US Department of Justice (DOJ) guarantees to afford all the officers, employees, and agents of the 'first in' amnesty applicant company immunity from prosecution. Specifically in the US, however, there is an even greater incentive for the company to come forward: even if a CEO was not heavily involved in the cartel activity,

\footnotetext{
${ }^{54}$ Donald Klawiter and Jennifer Driscoll, 'Sentencing Individuals in Antitrust Cases: The Proper Balance' (2009) 23(2) Antitrust Magazine 75, 77.

${ }^{55}$ Dan Kahan, 'Gentle Nudges vs Hard Shoves: Solving The Sticky Norms Problem' (2000) 67 U Chi L Rev 607.

56 ibid 608.

${ }^{57}$ US Department of Justice, 'Corporate Leniency Policy'

<http://www.justice.gov/atr/public/guidelines/0091.htm> accessed 3 July 2014.
} 


\section{The Criminal Enforcement of Antitrust Law - The Importance of Building an Enforcement Culture and How to Create it}

a more involved subordinate employee may be able to obtain immunity - under the individual leniency programme $\mathrm{s}^{58}$ - in exchange for a promise of testimony that the CEO and/or more senior executives had knowledge of, or had approved, the infringement. Therefore, if a company does not report unlawful conduct itself, an employee may come forward of their own accord and report the company's activities to protect himself or herself. As Scott Hammond explains in the context of DOJ's combining of corporate and individual leniency programmes:

The real value $\ldots$ of the Individual Leniency Programme is not in the number of individual applications we receive, but in the number of corporate applications it generates. It works because it acts as a watchdog to ensure that companies report the conduct themselves ... So long as one of its employees has individual exposure, the company remains at great risk. ${ }^{59}$

Efforts to criminalise antitrust offences elsewhere may be further hampered because of institutional makeup. Jurisdictions in Europe, for example, have an institutional heritage of applying administrative fines through administrative agencies against businesses, as opposed to criminal sanctions against individuals. Furthermore, a separate institution from cartel enforcement currently oversees criminal law enforcement, which would not be conducive to a successful criminalised antitrust regime. For instance, prosecutors may not prioritise antitrust cases ahead of rape and murder, or may be deterred by their unfamiliarity with antitrust more generally. ${ }^{60}$

In comparison, the US entrusts both civil and criminal enforcement of cartels to a specialist division within DOJ. In addition to avoiding the above pitfalls, this hybrid enforcement entity is better suited to running a successful leniency programme. This is because if enforcement were separated, neither institution might be able to accurately reassure potential leniency applicants. Indeed, Scott Hammond lists transparency and predictability as to how a company will be dealt with should it apply for leniency as cornerstones of an effective leniency programme. ${ }^{61}$ Kovacic also maintains that ' $[\mathrm{i}] \mathrm{f}$ there is any non-trivial doubt about the certainty of the government's commitment to abate the criminal sanctions, firms are likely to decline to report the misconduct'. ${ }^{62}$ It is worth noting that a solution to this asymmetry between

\footnotetext{
${ }^{58}$ US Departmentt of Justice, 'Individual Leniency Policy' <http://www.justice.gov/atr/public/guidelines/0092.htm> accessed 3 July 2014.

59 Scott Hammond, 'Cornerstones of an Effective Leniency Programme' (ICN Workshop on Leniency Programmes, Sydney, Australia, 22-23 November 2004) 11, 12.

${ }^{60}$ Shaffer, Nesbitt, and Waller (n 7) 27.

${ }^{61}$ Hammond, 'Cornerstones of an Effective Leniency Program' (n 59).

${ }^{62}$ William E Kovacic, 'Criminal Enforcement Norms in Competition Policy: Insights from US Experience' in Beaton-Wells and Ezrachi (n 19) ch 3.
} 
prosecutorial bodies and administrative competition authorities would be to stipulate within the law itself that competition authority decisions made with respect to leniency automatically bind the public prosecutor. ${ }^{63}$ In any case, for leniency to work, there must of course exist a credible threat of detection and punishment of the cartel ('heightened fear of detection'), ${ }^{64}$ which is all the more possible with a well-resourced and dedicated body in charge of both investigating and prosecuting antitrust cases.

Finally, the grand jury system is another distinguishing aspect of US antitrust enforcement. ${ }^{65}$ It allows DOJ to build a credible criminal cartel case even when documentary evidence is limited. ${ }^{66}$ It is enshrined in the Fifth Amendment that felony offences cannot be tried except on indictment by a grand jury. The grand jury decides not the guilt or innocence of a person, but whether enough evidence exists to bring a case to trial. Grand juries hear evidence presented by the prosecutor and utilise subpoenas to collect this evidence. It can subpoena documents, physical evidence, and witnesses to testify. ${ }^{67}$ As stated in United States $v$ Calandra: "The grand jury may compel the production of evidence or the testimony of witnesses as it considers appropriate... ${ }^{68}$ No judge is present, and counsel for the defence is not allowed to be in the grand jury room during proceedings.

For DOJ, then, bringing a case to a grand jury affords an opportunity to exploit its powers to help the investigation. Indeed, Sherman Act investigations can be very lengthy and complex and the evidence that is ultimately collected may not be enough for proof of guilt beyond reasonable doubt. With the grand jury, prosecutors can play individual targets against each other, as only DOJ knows exactly what information they themselves have and where it originated, and what information they still require to make or strengthen a case. DOJ can also offer immunity to targets for information on bigger targets. ${ }^{69}$ Moreover, just because a person was not indicted by a grand jury does not mean that they cannot be tried again: the principle of 'double jeopardy' would not apply, as they had not yet actually been tried. ${ }^{70}$

In conclusion, it is clear that America's approach to punishing cartels has been an evolutionary process, one grounded upon 'politics and public psychologies that others may

\footnotetext{
63 ibid.

${ }^{64}$ Hammond, 'Cornerstones of an Effective Leniency Program' (n 59) 5.

65 US Department of Justice, 'Antitrust Division Manual' (5th edn) section F, March 2014 <http://www.justice.gov/atr/public/divisionmanual/atrdivman.pdf > accessed 24 August 2014.

${ }^{66}$ Baker, 'Punishment for Cartel Participants in the US: A Special Model?' (n 19).

${ }^{67}$ Gregory Werden, Scott Hammond, and Belinda Barnett, 'Deterrence and Detection of Cartels: Using all the Tools and Sanctions' (26th Annual National Institute on White Collar Crime, Miami, Florida, March 2012 ) 13.

68414 US 338, 343 (1974).

${ }^{69}$ Baker, 'Punishment for Cartel Participants in the US: A Special Model?' (n 19).

70 This principle precludes a person from being tried for the same charge, or similar charges, again.
} 
regard as peculiarly American'. ${ }^{71}$ Amongst the unique procedural and investigatory tools at its disposal, perhaps the most defining feature of the US antitrust system is that all relevant stakeholders - politicians, judges, and the American public - agree that sending cartel participants to jail is the best way to achieve deterrence, ie prevent future violations of antitrust law. Public outcry and populist-driven frustrations engendered key political support for the formulation and implementation of antitrust law in the US at critical times (a bottom-up process). The Sherman and Clayton Acts were national landmarks 'created on the basis of populist outrage at the perceived abuses of Standard Oil and other high visibility villains'. ${ }^{72}$ DOJ was not involved and did not push the earlier political movements. It did not recommend the 1974 and 2004 milestones nor did it publicly voice support for these changes. The process was also gradual, and '[it] has taken almost a century in the US for incarceration to become routine for cartel participants who are caught'. ${ }^{73}$

If other governments do decide to criminalise their national antitrust laws (a top-down process), they must make efforts to obtain the necessary stakeholder support for such a regime. As Shaffer and others note, '[n]ot all publics are convinced that cartel offenses merit the criminal penalty of jail time' ${ }^{74}$ This is an issue in Europe, and it was particularly exemplified in the UK by its naivety towards creating and enforcing a criminal cartel offence.

\section{EUROPE AND THE UNITED KINGDOM}

The European Commission can only impose fines on undertakings which 'shall not be of a criminal nature' according to Article 23 (5) Regulation 1/2003. As Baker explains in the European context:

[C]artels [continue] to be viewed by the public and the politicians as a 'regulatory' problem subject to regulatory remedies ... Thus there does not yet seem to be the kind of broad basis of political support (or acceptance) that is probably necessary to generate support for criminalization on any broad scale in Europe. ${ }^{75}$

Harding also notes that at least outside of North America, the public appears to lack inherently criminal feelings towards price-fixing and similar practices. ${ }^{76}$

\footnotetext{
${ }^{71}$ Baker, 'Punishment for Cartel Participants in the US: A Special Model?' (n 19).

72 ibid.

73 ibid.

${ }^{74}$ Shaffer, Nesbitt, and Waller (n 7) 27.

75 Baker, 'Deterring Cartels - the Criminalization Dimension' (n 14) 3.

${ }^{76}$ Harding (n 15) 197.
} 
The significance of public and political attitudes towards specific types of behaviour can be analysed in light of the UK's attempt to create a criminal cartel offence. However, in contrast to the 'groundswell of concern' towards cartel activity in the US (a bottom-up process), the UK's move towards criminalisation was motivated by 'regulatory interests seeking to strengthen the regulatory armoury against cartels, [thereby creating] greater awareness and concern regarding cartel conduct than currently exists (a top-down process)' ${ }^{77}$ The collapse of the first contested jury trial - British Airways ${ }^{78}$ - on 10 May $2010,{ }^{79}$ under the UK's uninspiring criminal cartel regime, was the nadir of eight years of embarrassment for the OFT. ${ }^{80}$ Indeed, it has now been over a decade since the enactment of the highly rated criminal cartel offence and prosecutors have yet to obtain a single 'guilty' jury verdict; convictions have only been obtained through guilty pleas - in Marine Hose ${ }^{81}$ and most recently Galvanised Steel Tanks. ${ }^{82}$

The UK government's objective was to construct 'a world class competition regime for the UK' ${ }^{83}$ However, the following paragraphs will argue that the hollow rhetoric employed by enforcement officials and politicians did little to amass the necessary support from key stakeholders. The seriousness of cartels was not sufficiently relayed to enforcement officials, resulting in a flippant attitude towards prosecuting individuals. In particular, three factors will be critically assessed: the unpersuasive and dispassionate rhetoric of enforcement officials and criminalisation advocates; the carelessness in the handling of cases; and the inappropriate requirement of 'dishonesty' in the cartel statute's language.

First, with respect to unpersuasive rhetoric, the Department of Trade and Industry (DTI) began its campaign for criminalisation with a half-hearted mindset. Its intention was merely for criminal sanctions to be used alongside civil enforcement to bolster the administrative regime under section 2 Competition Act 1998. Individuals would be subject to criminal charges only in the most serious cases, with the majority being dealt with under the administrative

\footnotetext{
${ }^{77}$ Beaton-Wells, 'Criminalising Cartels: Australia's Slow Conversion' (n 18) 208.

${ }^{78} R v$ George and others [2010] EWCA Crim 1148.

79 David Teather, 'BA price-fixing trial collapses' The Guardian (London, 11 May 2010) <http://www.theguardian.com/business/2010/may/10/ba-price-fixing-trial-collapses > accessed 3 January 2016.

${ }^{80}$ Now the Competition and Markets Authority (CMA).

${ }^{81} R v$ Whittle \& Others [2008] EWCA Crim 2560.

82 Competition and Markets Authority, 'Director sentenced to 6 months for criminal cartel' (GOV.UK, 14 September 2015) 〈https://www.gov.uk/government/news/director-sentenced-to-6-months-for-criminal-cartel> accessed 3 January 2016; Caroline Binham, 'Former MD pleads guilty in UK industry price-fixing case' Financial Times (London, 17 June 2014)

<http://www.ft.com/cms/s/0/5c4d05b6-f60f-11e3-a038-00144feabdc0.html\#axzz3wBjZdqBT> accessed 3 January 2016.

${ }^{83}$ Department of Trade and Industry, 'Productivity and Enterprise: A World Class Competition Regime' (CM 5233, July 2001).
} 


\section{The Criminal Enforcement of Antitrust Law - The Importance of Building an Enforcement Culture and How to Create it}

regime. ${ }^{84}$ Such intentions did not resemble the fervent attitudes of DOJ and its serious stance on cartel activity. The following statement illustrates this difference:

The point is not how many individuals we send to prison ... We would rather that people did not end up operating cartels, but it is important if they do that we will have to send a message, both to the individual and society, that it is unacceptable and a serious offence. $^{85}$

Signs of optimism resurfaced after Marine $\mathrm{Hose}^{86}$ - constituting the first convictions obtained by the OFT for cartel activity - but there was little indication of solid, substantive commitment to criminalisation: 'Watch this space. We have criminal enforcement high on the agenda ... We're working hard and doing a lot' ${ }^{87}$

In May 2002, the then Director of Competition Enforcement at the OFT naively stated: [a]re these new powers necessary? Will they be used? The short answer to both questions is 'yes' ... [Serious cartel] activity is equivalent to theft. It has no redeeming features. However we will carefully select the cartels for criminal prosecutions, concentrating on the most serious ones. We expect there will be a relatively small number of prosecutions - but they will have a significant deterrent effect. The first prosecutions will reach the courts in a few years. ${ }^{88}$

Finally, the OFT Annual Plan for 2008-09 professed: 'We will continue to root out hard core cartel activity across the whole economy. We are committed to using our criminal powers where appropriate' ${ }^{89}$

The above statements were unconvincing not only as to how committed top enforcement officials really were, but also as to the frequency with which the new sanctions would be used. In comparison, DOJ statistics at this paper's outset are not indicators of lessening deterrence; instead, sentences are simply becoming more frequent and harsher. Moreover, the statements were predicated on a belief that criminalisation was actually desirable. They do not exactly inspire confidence and are a far cry from the rhetoric of US officials, which signalled commitment, passion, motivation, and desire. To compound this

\footnotetext{
84 ibid 7.37 .

85 Julian Joshua, 'DOA: Can the UK Cartel Offence be Resuscitated?' in Beaton-Wells and Ezrachi (n 19) citing Melanie Johnson MP, Hansard HC Standing Committee B, Enterprise Bill (23 April 2002) col. 169.

${ }^{86} R v$ Whittle \& Others [2008] EWCA Crim 2560.

${ }^{87}$ Julian Joshua, 'DOA: Can the UK Cartel Offence be Resuscitated?' in Beaton-Wells and Ezrachi (n 19) ch 6 citing Simon Pritchard, Senior Director for Mergers at the OFT, Speech at Times Law Panel Debate on Competition Law.

${ }^{88}$ Julian Joshua, 'DOA: Can the UK Cartel Offence be Resuscitated?' in Beaton-Wells and Ezrachi (n 19) ch 6 citing M Bloom, 'Key Challenges in Public Enforcement' (British Institute of International and Comparative Law) ${ }^{89}$ OFT, Annual Plan 2008-09 (The Stationery Office 2008) 20.
} 
lethargy, the UK cartel offence's profile (an awareness that it actually existed) was virtually invisible until British Airways. ${ }^{90}$ In essence, no effort was made to create and nurture an enforcement culture. Consequently, strong commitment and support from key stakeholders was not obtained.

Second, the incompetence of the OFT to deal with criminal cartel cases Illustrates this latter point - specifically, the collapse of the British Airways ${ }^{91}$ case. The offence related to the fixing of fuel surcharges on transatlantic passenger routes with Virgin Airlines; Virgin applied for corporate leniency and blew the whistle on British Airways. The case was regarded as the first real test of the criminal cartel offence, but the case collapsed due to a simple evidential disclosure error. Thousands of emails were not disclosed to British Airways, including 12,000 emails by a key prosecution witness, Paul Moore, Virgin Atlantic's former corporate affairs chief. In addition, the important task of document disclosure was delegated to the in-house counsel of Virgin and their external lawyers - the other party to the cartel and also the whistleblower. One might question, then, whether the OFT had adequate resources to collect the evidence in the first place. If not, then this may have been a direct consequence of not fostering stakeholder support during the criminalisation process - in particular, support from government, which ultimately determines a regulator's funding. The DTI's dubious commitment to criminalisation also lends itself to this contention.

Third and finally, the 'dishonesty' requirement in section 188 of the Enterprise Act 2002 has been heavily criticised and held to be one of the main reasons for the offence's failure, with the Hammond/Penrose Report acknowledging "the approach of "dishonesty" may be difficult for juries to understand'. ${ }^{92}$ This was particularly exemplified by Norris $v$ United States,${ }^{93}$ where price-fixing was held not to be dishonest in the absence of other discernible factors, for example fraud. The case concerned a CEO of the company Morgan Crucible who had been indicted by a US court in 2003 for fixing the prices of carbon products. DOJ commenced extradition proceedings to have the CEO extradited from the UK. The case demonstrated how the seriousness of the cartel offence was not yet reflected in judicial attitudes and public opinion. ${ }^{94}$ Indeed, as previously stated, criminalisation in the UK did not stem from

\footnotetext{
${ }^{90} R v$ George and others [2010] EWCA Crim 1148.

91 ibid.

92 Anthony Hammond and Roy Penrose, The Proposed Criminalisation of Cartels in the UK-A report prepared for the Office of Fair Trading (November 2001) [2002] UKCLR 97. 93 [2008] UKHL 16, [2008] 2 WLR 673.

${ }^{94}$ Andreas Stephan, 'The UK Cartel Offence: Lame Duck or Black Momba' (2008) CCP Working Paper 08-19, 11-16 <http://competitionpolicy.ac.uk/documents/8158338/8256111/CCP+Working+Paper+08-19.pdf> accessed 10 January 2016.
} 


\section{The Criminal Enforcement of Antitrust Law - The Importance of Building an Enforcement Culture and How to Create it}

public outcry and a bottom-up, backward-looking process. Rather, it was motivated by a forward-looking, top-down approach, sparked by international consensus calling for greater deterrents to cartels. ${ }^{95}$

Yet in ascertaining the applicability of criminal law to cartels, one must distinguish criminal law from civil law, and whether there is something special about criminal law that requires its separation from civil law more generally. ${ }^{96}$ For example, Lamond argues that as 'part of the value of criminal law lies in its constituting the most serious form of censure and condemnation open to a community - in singling out certain conduct for this treatment', the relationship between the legal and lay concept of crime is 'symbiotic' ${ }^{97}$ Essentially, criminal law's inherent ability to express severe disapproval of certain conduct in a community results in an interaction between ordinary people's conception of crime and the corresponding legal concept.

However, the criminal cartel offence is a stark example of criminal law being stretched beyond a body of law that stems from, and pre-assumes, moral delinquency. ${ }^{98}$ The UK cartel offence sought to expand criminal law into an area where there is no presupposition that the area it is venturing into is morally condemned. As the Court commented in Norris when rejecting an argument that public perceptions towards cartels had changed, it was 'impossible to find any contemporaneous observations to support the argument'. ${ }^{99}$ Julian Joshua even maintains that the UK public have 'traditionally been tolerant of, if not positively welcoming' of cartels. ${ }^{100}$ Furthermore, Andreas Stephan's survey indicated in 2008 that even after the offence's introduction, attitudes remained weak and a consensus did not exist that price-fixing was morally wrong. ${ }^{101}$

On this analysis, it could be argued that in deciding to criminalise certain conduct, lawmakers should not deviate too far from the type of behaviour that is generally regarded as being reprehensible or deserving of stigma - yet this is exactly what the UK did. The 'dishonesty' element in the criminal cartel offence arguably would have failed had it been put before a jury because it could not signal moral stigma - something that it relies upon and pre-

\footnotetext{
95 Jones and Williams (n 6) 1-26, 9.

96 ibid 10.

97 Grant Lamond, 'What is a Crime?' (2007) 27 Oxford Journal of Legal Studies 609, 612.

98 Jones and Williams (n 6) 11.

99 [2008] UKHL 16, [2008] 2 WLR 673, para 57.

100 Julian Joshua, 'Can the UK Cartel Offence be Resuscitated' in Beaton-Wells and Ezrachi (n 19) ch 6 relying on M O'Kane, The Law of Criminal Cartels: Practice and Procedure (OUP 2009) 17-22.

${ }^{101}$ Andreas Stephan, 'Survey of Public Attitudes to Price-Fixing and Cartel Enforcement in Britain' (2008) 5 Competition Law Review 123.
} 
supposes in order to function. The UK Cartel offence presumed moral censure existed when in fact none did, and as Williams explains, 'the law cannot pull itself up by its own bootstraps in this way'. ${ }^{102}$

Furthermore, the government has arguably failed to address this in its new reform of the cartel offence through the Enterprise and Regulatory Reform Act (ERRA) 2013. ${ }^{103}$ Removing the 'dishonesty' requirement may make convictions more straightforward, but it will not guarantee that censure will follow convictions or, more significantly, that judges will imprison those convicted. For instance, the new offence contains no mens rea requirement, compared to the US where criminal intent is required for Sherman Act violations in criminal prosecutions. Also, it could be argued that the strongest reason for criminalising cartels is that they are 'naked': they cannot be justified on efficiency grounds and can inflict serious economic harm. The legislation, however, does not reference these factors - factors which should arguably be made clear if an anti-cartel culture is to grow to the point where it is natural to view cartels as serious criminal activity. ${ }^{104}$

As the remainder of this paper will show, however, attitudes towards a specific type of behaviour can be shaped. It is clear that public support for a regime is important, mainly because juries are selected from the public. But it is also important in a further respect: to generate governmental support, which will in turn influence (or enhance if they already exist) the powers afforded to enforcement agencies/regulators. Indeed, past experience has shown that a regulator may be susceptible to attack from business interest groups if it does not have solid political backing. ${ }^{105}$ Political support is also necessary to ensure that other relevant agencies - prosecutors and the judiciary - are afforded powers to enforce the new regime. ${ }^{106}$ It is on these issues that we turn to examine the significance of creating and fostering an enforcement culture when deciding to criminalise cartels.

\section{E. THE IMPORTANCE OF AN ENFORCEMENT CULTURE}

In the framing of a legal system, the most important decision is the choice of sanctions to remedy infringements of law. This is because the choice of sanctions (eg injunctions; damages;

\footnotetext{
102 Rebecca Williams, 'Cartels in the Criminal Law Landscape' in Beaton-Wells and Ezrachi (n 19) ch 13.

103 s 47 ERRA 2013 removed the 'dishonesty' requirement to prove a cartel offence from s 188 Enterprise Act 2002 , and went on to include ss $188 \mathrm{~A}-\mathrm{B}$, which provide for defences and carve outs, ie 'circumstances in which cartel offence not committed'.

104 Jones and Williams (n 6) 19.

105 Christine Parker, 'The "Compliance Trap": The Moral Message in Responsive Regulatory Enforcement' (2006) 40(3) Law \& Society Review 591, 613.

${ }^{106}$ Beaton-Wells, ‘Criminalising Cartels: Australia’s Slow Conversion’ (n 18) 213.
} 


\section{The Criminal Enforcement of Antitrust Law - The Importance of Building an Enforcement Culture and How to Create it}

incarceration; director disqualification; or a mix of these) is 'fundamental to the formal calculations and informal intuition that determine whether corporate entities and natural persons will obey the law'. ${ }^{107}$ As the foregoing discussions have shown, antitrust law is at the centre of such debates, ie whether antitrust infringements should be subject to criminal sanctions. It is generally argued that only cartels should be subject to criminal sanctions, they being the most clear-cut and severe form of anticompetitive conduct. ${ }^{108}$ The following sections are to be held as consistent with this view.

A jurisdiction considering the use of criminal sanctions faces institutional challenges. Without domestic support, criminal sanctions may not have the desired effect 'to change business norms and behaviour so as to reduce significantly the incidence of serious cartel conduct'. ${ }^{109}$ Therefore, support from a variety of key stakeholders (including the regulator, government, general public, and judiciary) will be necessary for the success of criminalisation. ${ }^{110}$ Specifically, a competition policy system that utilises criminal sanctions must: i) develop a culture within enforcement agencies that encourages employees to treat certain acts as very serious offences and perceive them as deserving of aggressive investigation, ii) persuade external stakeholders (eg legislators and general public) that certain antitrust infringements deserve to be punished by criminal sanctions, and iii) convince courts and juries that infringers should be convicted and severely punished. ${ }^{111}$ The following paragraphs will explain why the support of each of these stakeholders is paramount. Following this, drawing on experience from the Australian Competition and Consumer Commission (ACCC), a rhetorical strategy will be put forward that can be used by regulators to attain the requisite support from two of the most important stakeholders: general public and government.

Regulator support is evidently vital for the success of criminal cartel enforcement. ${ }^{112}$ This will especially be the case if, as in Australia for example, the regulator is regarded as having political power and can therefore influence other stakeholders' perceptions about the criminalisation of antitrust infringements. Indeed, some stakeholders may not be entirely convinced of the justification for criminalisation and, as a result, the regulator must raise awareness about the evils of cartels to these constituents. ${ }^{113}$ Furthermore, the regulator must

\footnotetext{
${ }^{107}$ Kovacic (n 62).

${ }^{108}$ See Wills, 'Is Criminalization of EU Competition Law the Answer?' (n 23 ) 36-37.

${ }^{109}$ Beaton-Wells, 'Criminalising Cartels: Australia's Slow Conversion' (n 18) 206.

110 ibid 205.

${ }^{111}$ Kovacic (n 62).

112 Beaton-Wells, 'Criminalising Cartels: Australia's Slow Conversion' (n 18) 210.

113 ibid.
} 
actually use its newfound powers. As shown by the experience of the US, in order for the threat of imprisonment to be credible, there must be a realistic threat of detection and punishment, which is all the more probable if there exists a well-resourced and dedicated body in charge of investigating and prosecuting antitrust offences. The degree to which it can do this, however, will largely depend on its level of funding, which will of course rest upon the support level of another stakeholder: government.

Governmental support is plainly necessary to get the legislation enacted. ${ }^{114}$ In addition, regulators and courts must be afforded powers and resources that will enable them to enforce the new law - another derivative of governmental support. Just like regulator support, however, governmental support is also dependent upon the backing of another stakeholder: the general public. Public support is one of the biggest - if not the biggest - determinants of success for a criminal cartel offence. The US experience illustrates this contention by its bottom-up impetus, which propelled the use of criminal sanctions against cartels. Public support is significant in two respects: firstly, it is influential in generating political support for the regime which, as noted, determines the powers and funding afforded to other stakeholders (such as regulators). Secondly, juries are selected from the public, who are less likely to convict when enrolled to serve on a jury if they are oblivious to the seriousness of cartels. ${ }^{115}$

The importance of judicial support is also pertinent in this regard. Judges and juries must be willing to convict. To enhance deterrence, it is not enough for a criminal offence to lay dormant in a statute; it must be visibly enforced. Indeed, studies have shown that the risk of punishment has a far greater impact on deterrence than the punishment's severity. ${ }^{116}$ One obstacle, however, is that judges and juries may perceive corporate misconduct as not immediately threatening to an individual, as they would do for ordinary types of crime like rape or murder. ${ }^{117}$ The reluctance of judges to sentence has been an issue for Ireland, where courts have often suspended prison sentences for competition law infringements. ${ }^{118}$ In any event, support from the judiciary is particularly important in influencing the general public and

\footnotetext{
114 ibid 213.

115 ibid 220.

${ }^{116}$ US DOJ Bureau of Justice Statistics, Patrick Langan and David Farrington, Crime and Justice in the United States and England and Wales, 1981-1996; Raymond Paternoster, 'The deterrent effect of the perceived certainty and severity of punishment' (1987) 4 (2) Justice Quarterly 173-217.

117 Kovacic (n 62).

${ }^{118}$ Donald Baker, 'Punishment for Cartel Participants in the US: A Special Model?' (n 19); Patrick Massey and John D Cooke, 'Competition Offences in Ireland: The Regime and its Results' in Beaton-Wells and Ezrachi (n 19) $\operatorname{ch} 5$.
} 


\section{The Criminal Enforcement of Antitrust Law - The Importance of Building an Enforcement Culture and How to Create it}

their attitudes towards cartels. As Coffee maintains, 'the public learns what is criminal from what is punished, not vice versa'. ${ }^{119}$

\section{F. BUILDING AN ENFORCEMENT CULTURE}

It is clear that creating and enforcing a criminal cartel offence will be a complex undertaking. It will require efforts to generate awareness about the pernicious nature of cartels, along with support from a variety of key players who will be instrumental in the regime's success. Criminalisation of certain behaviour can significantly impact the operation of a legal system and it is therefore necessary to '[put] a premium on understanding a jurisdiction's existing legal and social norms and on developing an implementation programme that gains acceptance for criminal sanctions'. ${ }^{120}$ As Professor Andreas Reindl observes, criminalisation does not 'occur in a legal vacuum'. ${ }^{121}$ Social and political amenability towards criminal sanctions will vary across countries, and it is this challenge that gives rise to important implications for how a jurisdiction should go about criminalising antitrust violations.

In the aftermath of the global financial crisis, however, there exists a universal concept that countries across the globe have had to grapple with: inequality. Whilst debates about cartel activity have primarily focused on its nature and effects, less discussion has been afforded to critically analysing cartel criminalisation in the broader political sphere and from the general public's perspective. This is despite the fact that cartel criminalisation represents a categorical shift in economic policymaking, ie 'behaviour seen to damage the economy is now not merely illegal, but criminal' ${ }^{122}$ Indeed, the credibility of this view has been strengthened because of the global financial crisis, with families in some jurisdictions having to decide between buying food and paying their mortgage, ${ }^{123}$ or incurring food poverty in general. ${ }^{124}$

\footnotetext{
${ }^{119}$ John Coffee, 'Paradigms Lost: The Blurring of the Criminal and Civil Law Models - And What Can Be Done About it' (1992) 101 The Yale Law Journal 1875, 1889.

${ }^{120}$ Kovacic (n 62).

${ }^{121}$ ibid citing Andreas Reindl, 'How Strong is the Case for Criminal Sanctions in Cartel Cases?' in Cseres, Schinkel and Vogelaar (n 35).

${ }^{122}$ Caron Beaton-Wells, 'The Australian Conversion: How the Case for Cartel Criminalisation was Made' (2010) 1 New Journal of European Criminal Law 499, 500.

${ }^{123}$ Claire O'Sullivan, 'Families are being forced to choose between mortgage and food' Irish Examiner (Dublin, 5 September 2013) <http://www.irishexaminer.com/ireland/families-are-being-forced-to-choose-betweenmortgage-and-food-242030.html > accessed 25 July 2014.

${ }^{124}$ Emer Costello MEP, 'Thousands of people in Ireland can't afford a basic meal every second day' (The Journal, 17 December 2013) <http://www.thejournal.ie/readme/thosuands-of-people-in-ireland-cant-afford-a-basic-mealevery-second-day-1227846-Dec2013> accessed 25 July 2014; Amella Hill, 'Families struggle to eat healthily amid rising food bills and shrinking budgets' The Guardian (London, 18 November 2012) <http://www.theguardian.com/society/2012/nov/18/families-rising-food-prices-budgets > accessed 25 July 2014.
} 
Drawing on insights from Australia and the ACCC, the following paragraphs examine exactly how a regulator can persuade two key stakeholders - the general public and government - to be more receptive to the idea of punishing cartels with criminal sanctions. Three key pieces of rhetoric will be used: criminal sanctions as protecting the economy, criminal sanctions as policing big business, and criminal sanctions as promoting egalitarianism. All of these arguments, more or less, rely on the ever-growing and contentious issue of inequality, given that (as previously stated) almost every country is experiencing this issue to varying degrees. ${ }^{125}$ It will be concluded that now is the time for regulators to make their case for cartel criminalisation. They must leverage both the financial hardships currently being experienced by consumers and their resentment towards the financial industry and overly paid CEOs, in order to garner public and political support for a criminal cartel offence.

First, relying on criminalisation to protect the economy, many people are unaware of antitrust law in general, or that it protects the free market economy from which they benefit. Over the past several decades, as part of an extensive microeconomic reform programme, both Labour and Conservative governments in Australia have emphasised the benefits of competition. The reforms have included public service privatisation, trade liberalisation, and financial and labour deregulation. These have helped to advance economic prosperity, employment rates, income levels, and living standards. ${ }^{126}$ The inequality gap has also been somewhat reduced, with benefits flowing to both high and low income earners. ${ }^{127}$ Social attitude surveys reveal public support for these reforms, with Australians also viewing international trade as conducive to providing better consumer products. ${ }^{128}$ They also understand that living standards depend on a growing economy: they see the value in 'maintaining "a high level of economic growth", and are proud of Australia's economic achievements'. ${ }^{129}$

Conversely, social research also shows that Australians are uncertain about how much or to what degree free markets and trade are likely to improve their quality of life. In addition,

\footnotetext{
${ }^{125}$ Martin Wolf, 'A more equal society will not hinder growth' Financial Times (London, 25 April 2014). $\langle$ http://www.ft.com/cms/s/0/330931dc-c4ca-11e3-8dd4-00144feabdc0.html\#axzz2zuOyAhNT> accessed 13 August 2014.

126 OECD, OECD Reviews of Regulatory Reform - Australia: Towards a Seamless National Economy (15 February 2010).

${ }^{127}$ Beaton-Wells, 'The Australian Conversion: How the Case for Cartel Criminalisation was Made' (n 122) 499 citing Productivity Commission, Review of National Competition Policy Reforms, Report No 33 (28 February 2005) chs 3-4.

128 ibid 506 citing Michael Pusey and Nick Turnbull, 'Have Australians Embraced Economic Reform' in Shaun Wilson and others (eds), Australian Social Attitudes: The First Report (University of New South Wales Press 2005) ch 10.

${ }^{129}$ ibid.
} 


\section{The Criminal Enforcement of Antitrust Law - The Importance of Building an Enforcement Culture and How to Create it}

it seems that concerns have arisen about the widening of the income gap ${ }^{130}$ - a reflection of similar concerns worldwide. For example, a 2014 IMF study noted the rising inequality in advanced countries and the falling inequality in developing countries over the past 50 years. ${ }^{131}$

In light of these ambivalent public attitudes, it would make sense to communicate the values of competition when embarking on the process of criminalisation. This is exactly what Australia did. The ACCC chairman linked cartels to metaphors of disease and death, describing them as a 'cancer on our economy'. ${ }^{132}$ Competition was portrayed as having the ability to safeguard the free market reforms discussed above - reforms which were essential to Australia's economic welfare and prosperity. It was promulgated that by adopting a tough stance on cartels, free-market policies and the resulting economic prosperity would be protected 'by regulating to deter anti-competitive conduct that [threatened] the creativity and efficiency of the market'. ${ }^{133}$ The economic benefits of competition were especially emphasised in almost all public statements made by the ACCC and Parliament in support of criminalisation reform. ${ }^{134}$ As the Minister for Competition Policy and Consumer Affairs stated at the time of introducing the criminalisation Bill to Parliament,

Competition is the primary means of ensuring that consumers get the best product or service for the lowest price possible. ... Cartel conduct harms consumers, businesses and the economy by increasing prices, reducing choice and distorting innovation processes. $^{135}$

The beauty of this statement lies in its simplicity. It was not littered with jargon or overly technical economic theory and terms. 'There was confidence, however, that laypeople would understand a simplified message about the effects of such conduct on them as consumers, namely, that cartels raised prices'. ${ }^{136}$ Indeed, consumers may not understand the technicalities of a cartel, but in the wake of the financial crisis and the ensuing proliferation of household debt, ${ }^{137}$ they will be more attuned to understanding when they have been ripped

\footnotetext{
130 ibid 507.

${ }^{131}$ Jonathan Ostry, Andrew Berg, and Charalambos Tsangarides, 'IMF Staff Discussion Note: Redistribution, Inequality, and Growth' (February 2014) < http://www.imf.org/external/pubs/ft/sdn/2014/sdn1402.pdf $>$ accessed 13 August 2014, 13.

132 Beaton-Wells, 'The Australian Conversion: How the Case for Cartel Criminalisation was Made' (n 122$) 507$. 133 ibid.

134 ibid footnote 43.

${ }^{135}$ Chris Brown, Minister for Competition Policy and Consumer Affairs Commonwealth, Parliamentary Debates, House of Representatives, 3 December 2008, 12309.

136 Beaton-Wells, 'The Australian Conversion: How the Case for Cartel Criminalisation was Made' (n 122$) 508$.

${ }^{137}$ Nichola Saminather, 'Australian Regulators Watch as Debt Drives Up Prices: Mortgages' (Bloomberg, 28 July

2014) <http://www.bloomberg.com/news/2014-07-27/australian-regulators-watch-as-debt-drives-up-pricesmortgages.html $>$ accessed 29 July 2014.
} 
off. ${ }^{138}$ One Parliamentary member illustrates this point by detailing her experience in dealing with members of the public: 'Nothing irritates Australian consumers more than paying too much for goods and services that are offered in the market place. They absolutely hate it, and they talk to us politicians about it all the time'. ${ }^{139}$

In addition to this rhetoric, the ACCC's victory in Visy could not have come at a more apposite time: ${ }^{140}$ just before the 2008 financial crisis. The case ended in record penalties being imposed on one of Australia's richest business people, Richard Pratt. The victory acted as a catalyst in the final push for introducing criminalisation of cartels in Australia. Heerey J's judgment was particularly damning, and aptly underlined the adverse effects that a cartel can inflict on an ordinary consumer: 'Every day every man, woman and child would use or consume something that at some stage has been transported in a cardboard box. The cartel in this case therefore had the potential for the widest possible effect'. ${ }^{141}$

These rhetorical efforts, along with the implications of Visy, were harnessed by criminalisation proponents in debates on criminalisation reform. They were used as a medium through which the relevance and importance of the reform to the general public and government could be underscored. In the aftermath of the financial crisis, regulators in other jurisdictions should take heed of the ACCC's efforts in promoting criminalisation, which were put forward in a manner with which both citizens and government could empathise. Such rhetoric leverages the financial hardship currently being experienced by consumers and markets criminalisation in a way that highlights its ability to protect the economy and protect consumers from having to pay higher prices - something which all consumers want, especially in times of austerity and economic recession.

Mixed feeling towards 'big business' was also relied upon when making the case for cartel criminalisation in Australia. ${ }^{142}$ Whilst Australians take pride in the success of high profile business executives, social attitudes research simultaneously indicates that many Australians are of the view that 'big business should have less power'. ${ }^{143}$ It seems, therefore, that trust towards big business has declined, fuelled by wide-ranging media coverage reporting corporate misconduct, in particular regarding well-known individuals. Mistrust has also been

\footnotetext{
${ }^{138}$ Interview with Graeme Samuel AO, ACCC Chairman, Sarah Court, ACCC Commissioner and Marcus Bezzi, ACCC Executive General Manager, Enforcement and Compliance (Melbourne, 23 March 2010) (ACCC Interview).

${ }^{139}$ Nola Marino, Commonwealth, Parliamentary Debates, House of Representatives, 11 February 2009, 891-2.

${ }^{140}$ ACCC v Visy Industries Holdings Pty Ltd (No 3) [2007] FCA 1617.

${ }^{141}$ Visy (2007) 244 ALR 673, [312].

${ }^{142}$ Beaton-Wells, 'The Australian Conversion: How the Case for Cartel Criminalisation was Made' (n 122) 513.

143 ibid footnote 71.
} 


\section{The Criminal Enforcement of Antitrust Law - The Importance of Building an Enforcement Culture and How to Create it}

compounded by political crackdowns on senior executive pay packages in times of economic downturn. ${ }^{144}$ This latter point - executive pay packages - is a globally controversial and topical debate at present. For example, executive remuneration has risen substantially not just for FTSE 100 companies in the wake of the financial crisis, ${ }^{145}$ but also companies more generally since the 1980s. ${ }^{146}$ Whilst excessive risk-taking was a contributory cause of the crisis, it was arguably exacerbated by executive remuneration structures. As Bebchuk and Spamann observe, 'excessive risk-taking in the financial sector ... played an important role in the major financial crisis [and] there is widespread concern that executive compensation arrangements could have encouraged [this behaviour]'. ${ }^{147}$

Yet in times of such crises the shortfall of a country's exchequer is often borne by ordinary citizens. Indeed, the economic crash led to austerity measures in many jurisdictions. It is no wonder, then, that ordinary taxpayers - footing the bill for the mistakes of 'financial fat cats' - feel aggrieved. For instance, despite both Europe and the US experiencing widespread unemployment as a consequence of the financial collapse, investment bankers and CEOs received, and continue to receive, ${ }^{148}$ exorbitant pay packets - some even larger than before. ${ }^{149}$ These reports of burgeoning executive remuneration have traditionally been met with 'predictable gasps about over-payment'. ${ }^{150}$ Conventional notions of fairness have become distorted, fomenting social unrest ${ }^{151}$ in many countries. ${ }^{152}$ With jurisdictions like Switzerland

\footnotetext{
144 ibid 514.

145 Julia Finch and Simon Bowers 'Executive pay keeps rising, Guardian survey finds' The Guardian (London, 14 September 2009) <http://www.theguardian.com/business/2009/sep/14/executive-pay-keeps-rising> accessed 13 August 2014.

146 Xavier Gabaix and Augustin Landier, 'Why has CEO Pay Increased so Much?' (2008) 123 The Quarterly Journal of Economics 49.

${ }^{147}$ Lucian Bebchuk and Holger Spamann, 'Regulating Bankers' Pay' (2010) 98 Georgetown Law Journal 247, 249.

148 Jill Treanor, 'Banking bonuses worldwide up 29\% as City of London fares even better' The Guardian (London, 11 March 2014) <http://www.theguardian.com/business/2014/mar/11/banking-bonuses-rise-city-of-london> accessed 17 April 2014.

${ }^{149}$ Nick Fletcher, 'Executive Pay Rises While Shareholder Earnings Fall, Says MM\&K Survey' The Guardian (London, 5 July 2010) <http://www.theguardian.com/business/2010/jul/05/executive-pay-rises-shares-fall> accessed 4 April 2016.

${ }^{150}$ James Wade, Charles O’Reilly and Timothy Pollock, 'Overpaid CEOs and Underpaid Managers: Fairness and Executive Compensation’ (2006) 17 Organization Science 527.

${ }^{151}$ David Friedrichs, 'Exorbitant CEO Compensation: Just Reward or Grand Theft?' (2009) 51 Crime, Law \& Social Change 45.

152 Janis Emmanouilidis, 'Greece: EU must Prevent Social Domino Effect' The Guardian (London, 3 May 2010) <http://www.theguardian.com/commentisfree/2010/may/03/debt-crisis-greece> accessed 4 April 2016; Valur Gunnarsson, 'Iceland's Coalition Struggles to Survive Protests' The Guardian (London, 22 January 2009) <http://www.theguardian.com/world/2009/jan/22/iceland-protests-recession> accessed 4 April 2016; Peggy Hollinger, 'French Stage Mass Pension Protest' Financial Times (London, 27 May 2010) 〈http://www.ft.com/cms/s/0/ac6640b8-69c2-11df-8432-00144feab49a.html\#axzz44mRxwlmT> accessed 4 April 2016.
} 
having recently voted on national minimum wage increases ${ }^{153}$, the controversy over executive remuneration is really just a sub-debate of the wider discourse: inequality. It would seem, therefore, that executive remuneration has axiomatically become a political quandary, not just a financial stigma.

On this analysis, cartel criminalisation would have signalled to the Australian public that government was prepared to become tough on big business. The exclusion of small businesses being subject to the reform was also key, portraying the ACCC as a 'watchdog' and egalitarian. The case for criminal sanctions was as much a moral one as it was economic. The ACCC said that cartel activity was solely for the "enrichment of greedy companies and executives that engage in it at the expense of Australian consumers and "honest" Australian businesses'. ${ }^{154}$ Framed in this manner, criminalisation was advanced not just in a way with which the public could greatly empathise, but was also made politically palatable as it offered a chance for government to signal to their electorate that they were prepared to become tough on 'big business'. Public resentment towards 'big business' was exploited, whilst criminalisation also offered the opportunity for government to repair its image of being 'run for a few big interests' rather than 'run for the benefit of all'. 155

In this context, the immorality of cartels could prove a useful argument in jurisdictions where there exists public resentment towards 'big business' and lavishly paid CEOs because it plays up the 'little man versus big man' debate - one which is really just a tangent of the much broader controversy of inequality. For example, last year Swiss voters approved the 'fat-cat initiative', introducing binding 'Say on Pay' in Switzerland. ${ }^{156}$ This again attests to the notion that executive remuneration is really a sub-set of broader political issues regarding wealth distribution, specifically, the increasing inequality gaps in developed countries. ${ }^{157}$ Indeed, regulating the tension between market dynamism and effective redistribution is one of today's

\footnotetext{
${ }^{153}$ Catherine Bosley, 'World's Highest Minimum Wage on Ballot in Switzerland' (Bloomberg, 19 April 2014) <http://www.bloomberg.com/news/2014-04-13/world-leading-25-hourly-wage-floor-roils-swiss-businessesjobs.html> accessed 20 April 2014.

${ }^{154}$ Beaton-Wells, 'The Australian Conversion: How the Case for Cartel Criminalisation was Made' (n 122$) 517$. 155 ibid 514.

156 This proposes that shareholders must approve top-level director remuneration packets - along with future amendments - through a proxy vote. 'Say on Pay' can be non-binding (advisory) or binding.

${ }^{157}$ Catherine Bosley, 'World's Highest Minimum Wage on Ballot in Switzerland' (Bloomberg, 19 April 2014) <http://www.bloomberg.com/news/2014-04-13/world-leading-25-hourly-wage-floor-roils-swiss-businessesjobs.html> accessed 13 August 2014.
} 


\section{The Criminal Enforcement of Antitrust Law - The Importance of Building an Enforcement Culture and How to Create it}

defining political challenges - a challenge which could prove a blessing in disguise for cartel criminalisation proponents. ${ }^{158}$

The push for criminalisation in Australia also appealed to the country's ethos of egalitarianism, specifically the ideal that all persons should be dealt with equally before the law was relied upon. A 2003 study showed that 81 percent of respondents agreed with the statement 'when big businesses break the law they often go unpunished' ${ }^{159} 40$ percent strongly agreed. Evidence also revealed that Australians perceived the criminal justice system as too lenient, with recent surveys evincing a consensus about the proposition that there should be 'stiffer sentences' for those who 'break the law'. ${ }^{160}$

Utilising the idea of equality before the law could prove advantageous for other jurisdictions whose citizens hold much bitterness and resentment towards white-collar criminals, ${ }^{161}$ as analogies can be drawn between these offenders and cartelists. ${ }^{162}$ Ireland is a prime example: more than six years after the banking collapse, an inquiry is only now starting to take place, stemming from public and political outrage. ${ }^{163}$ Furthermore, the most culpable bank - Anglo Irish Bank (now IBRC) - recently saw two of its executives being found guilty of illegal lending, and yet the judge decided not to impose any prison sentence. ${ }^{164}$ This again exemplifies the reluctance of judges in this jurisdiction to impose custodial sentences for whitecollar crimes generally.

'Such disparity ... contributes to the widespread perception among all segments of [a] population that $\ldots$ courts are not administering evenhanded justice' ${ }^{165}$ Indeed, reluctance to sentence may ultimately prove fatal to public confidence in a jurisdiction's legal system. Crimes by companies undermine the law's moral foundations and ' $[\mathrm{t}] \mathrm{his}$ erosion of confidence

\footnotetext{
${ }^{158}$ Martin Wolf, 'A more equal society will not hinder growth' Financial Times (London, 25 April 2014). <http://www.ft.com/cms/s/0/330931dc-c4ca-11e3-8dd4-00144feabdc0.html\#axzz2zuOyAhNT> accessed 13 August 2014.

${ }^{159}$ Beaton-Wells, 'The Australian Conversion: How the Case for Cartel Criminalisation was Made' (n 122) 518, footnote 103 .

160 ibid footnote 104.

161 ibid 520 .

162 Cartelists being nothing more than 'well-dressed thieves': Caron Beaton-Wells, 'The Australian Conversion: How the Case for Cartel Criminalisation was Made' (n 122) 519.

163 Jamie Smyth, 'Dublin plans Anglo Irish inquiry amid public anger' Financial Times (London, 25 June 2013) <http://www.ft.com/cms/s/0/d519dcae-ddb4-11e2-892b-00144feab7de.html\#axzz44mRxwlmT> accessed 4 April 2016; Fionnan Sheahan and Fiach Kelly, 'Anglo Tapes: Public rage pushes Coalition to choose bank inquiry option’ Irish Independent (Dublin, 28 July 2014) <http://www.independent.ie/business/irish/anglo/anglo-tapespublic-rage-pushes-coalition-to-choose-bank-inquiry-option-29376078.html> accessed 4 April 2016.

${ }_{164}$ Neil Maidment, 'Ireland opens banking inquiry after bankers escape jail' Reuters (Dublin, 30 April 2014) <http://www.reuters.com/article/2014/04/30/ireland-banks-inquiry-idUSL6N0NM4Q720140430> accessed 19 August 2014.

165 Alan Dershowitz, 'The Paper Label Sentences: Critiques' (1976-1977) 86 Yale Law Journal 619, 628.
} 
in the law is increased when it is perceived that blue-collar criminals go to jail and white-collar criminals do not'. ${ }^{166}$ This is just another form of inequality - one which is not purely about income. As an OECD report explains,

[W] hen we talk about inequality, we must talk about more than income. Employment prospects, job quality, health outcomes, education and opportunities to build wealth over time matter for people's well-being and are heavily determined by their socioeconomic status. ${ }^{167}$

It is clear that in contrast to the UK experience, Australia's policymakers and regulators took a far more pragmatic and holistic stance on their journey toward successful cartel criminalisation. The process was conducted in a manner that readily appealed to certain stakeholders - in particular, those whose support and participation would be vital for effective enforcement. In essence, they sought 'first to understand, then to be understood', ${ }^{168}$ resulting in an astute marketing strategy for cartel criminalisation - one which had the potential to ameliorate stakeholders' concerns and ensure better standards of living.

\section{G. CONCLUSION}

Cartels are the most serious violation of antitrust law. They have no justifiable purpose and 'serve only to rob consumers of the tangible blessings of competition'. ${ }^{169}$ Criminalising cartels is rationalised on the basis that because it is company individuals who engage the cartel, sanctions should be levied on the individuals themselves in order to achieve proper deterrence. As Liman contends: 'To the businessman ... prison is the inferno, and conventional risk-reward analysis breaks down when the risk is jail. The threat of imprisonment, therefore, remains the most meaningful deterrent to antitrust violations'. ${ }^{170}$ Moreover, the risk of individuals instigating a cartel is compounded in a recession, as managers are under pressure to achieve targets but under more difficult conditions.

The US has been spoilt with success by its own criminalised antitrust regime. Yet it is a success that other jurisdictions have struggled to emulate. This paper has argued that the reason for such shortcomings has primarily been down to the lack of an enforcement culture. Criminal antitrust enforcement in the US was a bottom-up process, with key stakeholders -

\footnotetext{
166 Donald Baker and Barbara Reeves, 'The Paper Label Sentences: Critiques' (1976-1977) 86 Yale Law Journal $619,620$.

167 OECD, All On Board: Making Inclusive Growth Happen (2014) 1.

${ }^{168}$ Stephen R Covey, The 7 Habits of Highly Effective People (25th Anniversary Edn, Rosetta Books 2015).

169 Werden, Hammond, and Barnett (n 67) 2.

${ }^{170}$ Arthur Liman, ‘The Paper Label Sentences: Critiques' (1976-1977) 86 Yale Law Journal 619, 630-631.
} 


\section{The Criminal Enforcement of Antitrust Law - The Importance of Building an Enforcement Culture and How to Create it}

politicians, the public, and enforcement agencies - all recognising the deterrent value of such a regime. As Scott Hammond maintains: ' ...the most effective way to deter and punish cartel activity is to hold culpable individuals accountable by seeking jail sentences'. ${ }^{171}$ There exists a strong consensus in the US that antitrust violations should be dealt with in much the same manner as criminal behaviour. This has significantly facilitated the use of criminal sanctions for Sherman Act violations. In contrast, support from the aforementioned stakeholders in other jurisdictions seems less apparent. Indeed, '[n]ational competition authorities outside of the [US] recognise ... public education about the evils of [cartels] as a central component of their missions'. ${ }^{172}$ The UK's lacklustre criminal cartel offence is an example of what can result from failing to develop an enforcement culture. ${ }^{173}$

Educating the public is just one aspect, however. This paper has demonstrated both the importance and interrelatedness of all key players in the process of criminalisation. Enforcement agencies need funding and resources, which depends on the level of governmental support, which in turn can be influenced by the level of public support. Moreover, judges must be willing to impose custodial sentences and juries must be prepared to convict for deterrence to work. Juries are selected from the public, thereby necessitating public support, and judges must be afforded powers to enforce the new offences, therefore necessitating governmental support. Thus, the support of all key constituents is circular and interconnected, which is why a strong enforcement culture is so fundamental to the success of cartel criminalisation.

Finally, this paper advanced rhetorical strategies for building an enforcement culture. In the aftermath of the financial crisis, regulators, in their campaign for criminalisation must take advantage of this opportune timing. General notions of financial hardship and inequality can be leveraged in emphasising the damaging effects of cartels on consumers. Indeed, a 2014 OECD Report notes 'the gap between the rich and poor has risen even faster since the global financial crisis than it did in the previous decade' and ' $[\mathrm{t}]$ he average income of the richest 10 percent is now about 9.5 times that of the poorest 10 percent on average in OECD countries, up from 7 times 25 years ago' ${ }^{174}$ Additionally, inequality is not just about income. Socioeconomic status influencing treatment before the law is another common feature of the current crisis, with those responsible often going unpunished.

\footnotetext{
${ }^{171}$ Scott Hammond, 'The Evolution of Criminal Antitrust Enforcement Over the Last Two Decades' (n 11).

172 Shaffer, Nesbitt, and Waller (n 7) 27.

173 ibid.

${ }^{174}$ OECD (n 167) 9.
} 
These rhetorical strategies engage with why cartel criminalisation is necessary something which the UK government was criticised for not doing. ${ }^{175}$ The strategies do this in a manner that exploits the universal concept of inequality, making cartel criminalisation both publicly desirable but also politically palatable. The appeal to government of criminal antitrust enforcement should be clear. Governments wishing to retain power over the long-term, particularly in forthcoming elections given consumers' (ie the electorate's) current financial status, would surely be amenable to a reform that could better ensure competitive prices for goods and services. In the aftermath of the global recession, living standards are a consumer's greatest concern.

175 Jones and Williams (n 6) 8-9. 